\title{
平面宇宙ロボットの 2 自由度アームによる姿勢制御*1 Attitude Control of a Planar Space Robot Using Two Degrees of Freedom Arm
}

\author{
吉 河 章 二*2 $\cdot$ 山田 克 彦*2
}

Shoji Yoshikawa and Katsuhiko Yamada

Key Words : Spacecraft, Guidance and Control, Space Robot, Attitude Control, Nonholonomic Systems

\begin{abstract}
This paper discusses a feedback controller for the planar space robot's attitude and hand position. Two types of feedback controllers are investigated for a robot with a two degrees of freedom arm: control with a sliding plane and control with time-variant terms. The characteristics of the closed system under these controllers are studied using the derived analytical solutions of the state variables. The effects of the estimation error in the robot's mass parameter are also discussed. Numerical simulations are given to show the validity of the controllers.
\end{abstract}

\section{1.はじめに}

宇宙ロボットはアームの運動によって本体の姿勢が変動 する. 從来は、ロボットアームや衛星間通信アンテナのよ うな可動部の動きに伴って生じるこのような本体の姿勢の 変動を, 姿勢外乱として扱ってきた。すなわち, 動きに伴 って生じる姿勢変動分を予測して姿勢制御でフィードフォ ワードし，姿勢変動を抑制するのが通例であった ${ }^{1,2)}$.こ こで見方を変えて，アームの運動に伴って生じる姿勢の変 動を姿勢制御に利用することを考える.

実際の宇宙ロボットにはモーメンタムホイールやスラス 夕のような姿勢制御のためのアクチュエータが搭載される ので，通常の運用形態でアームを用いて姿勢を制御する必 要がない.しかし, 故障により姿勢制御のためのアクチュ エータを使用できない場合の機能几長として有効である. また，小型の宇宙ロボットの場合には軌道制御と姿勢制御 の両方をスラスタで行うことが考光られるが，その場合に サービス対象の近傍においてスラスタによる対象の污染や 外乱などを避けるためにアームで姿勢を微調整することが 有効であろう.

さて，このような宇宙ロボットの姿勢をアームの運動に よって制御する問題は，アームの軌道計画という開ループ 制御の問題として定式化され，文献 $3 ， 4)$ 他多くの研究が ある。さらに，外乱やモデル化誤差などにロバストである ためには閉ループ制御（フィードバック制御）であること が望ましい.しかし，この問題がいわゆる非ホロノミック 系の制御問題に含まれ，連続な状態フィードバックによっ

\footnotetext{
*1 1998 年 5 月 26 日，第 21 回宇宙技衛及び科学の国際シンポジウ 厶 (21st International Symposium on Space Technology and Science）にて一部発表. 平成 10 年 11 月 19 日原稿受理

$* 2$ 三菱電機 (株) 先端技術繶合研究所
}

て平衡点を漸近安定化することができないことが知られて いる5．そのため，さまざまなフィードバック制御則が提 案されている.その代表的なタイプとして以下のものが举 げられる.

タイプ A：最初にアームの軌道を計画し，その軌道を たどるようにフィードバックする方法

タイプ B：ある特異な点を除いて連続的なフィードバッ ク則を設計する方法

タイプC：時間に陽に依存する項を導入する方法

タイプ D：離散的にフィードバックする方法6)

本稿では, 2 自由度のアームを 1 本持つ宇宙口ボットの 平面運動を考え，タイプ BとタイプCの 2 つの姿勢制御 則を検討する。これら 2 つの制御系の解析解を導出し, 収 束特性を明らかにする，また，モデル化誤差として質量パ ラメータの推定誤差が収束特性に及ぽす影響について考察 する.数値シミュレーションにより制御則の有効性を確認 する。

\section{2. 基礎方程 式}

2.1 平面宇宙ロボットのモデル 第 1 図に示すよう な, 2 自由度のアームを 1 本持つ宇宙ロボットの平面運動 を考える. 宇宙ロボットには外乱が働かないものとする. アームの質量をアーム先端のハンドにおける集中質量で代 表できるものとし，またハンドを慣性座標系において任意 の位置に動かせるものとする。

記号の定義は以下の通り。

$$
\begin{aligned}
m_{s}, i_{s} & : \text { 本体の質量および慣性モーメント } \\
m_{h} & : \text { ハンドにおける集中質量 } \\
O_{1} & : \text { 系全体の質量中心位置 } \\
O_{1}-x_{r} y_{I} & : \text { 慣性座標系 } \\
O_{B} & : \text { 本体の質量中心位置 }
\end{aligned}
$$




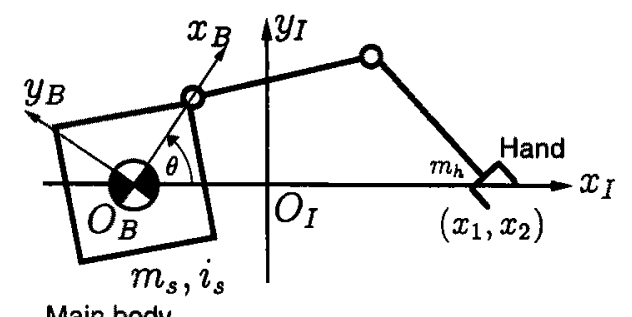

Main body

第1図 平面宇宙ロボットのモデル

$O_{B}-x_{B} y_{B}:$ 本体に固定した座標系

$\theta:$ 本体の姿勢角 $\left(x_{B}\right.$ 軸が $x_{I}$ 軸になす角)

$x_{1}, x_{2}$ : 慣性座標系におけるハンド位置の $x, y$ 成分 $\boldsymbol{u}=\left(u_{1} u_{2}\right)^{T}:$ ハンドの速度指令值

$\dot{w}:$ 変数 $w$ の時間微分

この宇宙ロボットの運動は次式で記述される。第 1 式 は，ハンドの速度指令がただちにハンド速度として実現さ れることを表す．第 2 式は，角運動量保存則を表す．第 2 式において $a$ は質量パラメータの一種で,アームの運動 が生じる姿勢変動の大きさを表す.

$$
\begin{aligned}
& \dot{x}_{1}=u_{1}, \quad \dot{x}_{2}=u_{2} \\
& \dot{\theta}=\alpha\left(-\dot{x}_{2} x_{1}+\dot{x}_{1} x_{2}\right) \\
& \alpha \equiv \frac{m_{h}\left(m_{s}+m_{h}\right)}{i_{s} m_{s}}
\end{aligned}
$$

2.2 問題設定 制御の目標は,アームの初期位置が $\left(x_{1 s}, x_{2 s}\right)$ で本体の初期姿勢が $\theta_{s}$ のときに，ア一ムが目標 位置 $\left(x_{1 f}, x_{2 f}\right)$ に移動して本体の姿勢が $\theta_{f}$ になるような適 切な速度指令值 $\boldsymbol{u}$ を生成することである。

ここで, 原点が目標值になるように状態変数を再定義す る.

$$
X_{1}=x_{1}-x_{1 f}, \quad X_{2}=x_{2}-x_{2 f}, \quad X_{3}=\theta-\theta_{f}
$$

このとき運動方程式 (1)，（2）は次式のように書き直され る.

$$
\begin{aligned}
& {\left[\begin{array}{c}
\dot{X}_{1} \\
\dot{X}_{2}
\end{array}\right]=u} \\
& \dot{s}=\alpha\left(-X_{1} \dot{X}_{2}+\dot{X}_{1} X_{2}\right) \\
& s \equiv X_{3}+\alpha\left(x_{1 f} X_{2}-x_{2 f} X_{1}\right)
\end{aligned}
$$

以下では，この問題に対して2つのフィードバック制御 則を検討し, 閉ループでの系の状態変数の近似解析解を求 めて状態変数の収束特性を明らかにする. 制御則の設計に あたり，アームの位置 $\left(x_{1}, x_{2}\right)$ および本体の姿勢角 $\theta$ が常 に正確にわかるものとする。また, 式(6)より質量パラメ 一タ $\alpha$ の推定值に誤差が含まれるときには変数 $s$ の推定 值に愦差が含まれるので， $\alpha$ の推定誤差が収束特性に及ほ す影響について考察する。

\section{3. 滑り面を用いる制御}

3.1 制御則の設計 非ホロノミックなシステムの制御 方法の1つに，滑り面の概念を用いる方法がある.ここで 定義する滑り面は，もし初期にその滑り面上にあるときは

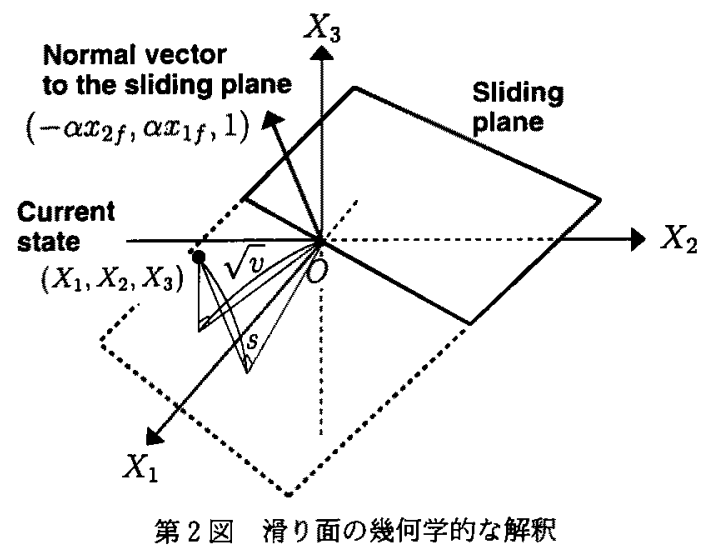

その面に沿って原点まで状態を移すことができるような面 である、このとき制御は、滑り面に状態を引き笴せる制御 と滑り面上に状態があるときにその状態を原点まで移す制 御とから構成される．例えば，移動口ボットのようにシス テムがチェイン形式で表される場合について，文献 7)で 制御則が提案されている。本節では，文献 7)の方法を式 (4)，（5）で表されるようなシステムに適用することを考 える.

制御則を以下のように設定する．後述するように，右辺 第 1 項 $\boldsymbol{u}_{s}$ が滑り面に状態を引き寄せる制御で，第 2 項 $\boldsymbol{u}_{v}$ が滑り面に沿って状態を原点に移す制御に相当する．定数 $\sigma, k_{s}$ はフィードバックケ゚インで，次節で述べるように安 定性の理由から $\sigma>k_{s}>0$ にとる。

$$
\begin{aligned}
& \boldsymbol{u}=\boldsymbol{u}_{s}+\boldsymbol{u}_{v} \\
& \boldsymbol{u}_{s}=-\sigma \frac{s}{\alpha v}\left[\begin{array}{cc}
0 & 1 \\
-1 & 0
\end{array}\right]\left[\begin{array}{l}
X_{1} \\
X_{2}
\end{array}\right] \\
& \boldsymbol{u}_{v}=-\left[\begin{array}{cc}
k_{s} & 0 \\
0 & k_{s}
\end{array}\right]\left[\begin{array}{l}
X_{1} \\
X_{2}
\end{array}\right] \\
& v=X_{1}^{2}+X_{2}^{2}
\end{aligned}
$$

原点を通り法線べクトル $\left(-\alpha x_{2 f}, \alpha x_{1 f}, 1\right)$ を持つ平面を滑 り面と定義すると, $s$ は状態と滑り面との距離を表し， $\sqrt{v}$ は目標点からのアームの位置誤差を表す（第 2 図を参 照).

$$
\begin{aligned}
& \text { 制御則 }(7) \text { をシステム }(4) ，(5) \text { に適用すると } \\
& \dot{s}=-\sigma s \\
& \dot{v}=-2 k_{s} v
\end{aligned}
$$

が成り立つ. 式(11)，(12)より以下のことがわかる.

（1）sとvは 0 に指数収束する，したがって定義式 (6)，(10)ょり $X_{1}, X_{2} ， X_{3}$ も原点に指数収束する.

（2）sの指数収束に注制御項 $\boldsymbol{u}_{s}$ が，また $v$ の指数収束 には制御項 $\boldsymbol{u}_{v}$ がそれぞれ単独に寄与している。すなわ ち， $\boldsymbol{u}_{s}$ が状態と滑り面との距離 $s$ を縮め， $\boldsymbol{u}_{v}$ が距離 $s$ を 保ちつつアームの位置譔差を小さくする，したがって， $u_{s}$ が滑り面に状態を引き寄せる制御で， $\boldsymbol{u}_{v}$ が滑り面に沿 って状態を原点に移す制御に相当する。

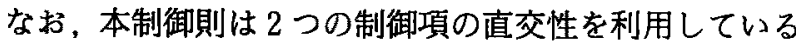
ので, $n$ 自由度のアームに拡張するためには適切な直交性 
を見いだすことが必要になり，拡張は容易でない。また， 式 $(8)$ より $v=0 て ゙ ~ s \neq 0$ のときに制御量 $\boldsymbol{u}_{s}$ の大きさが無

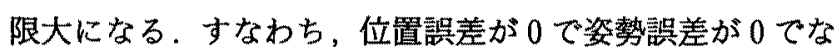
いとき，アームを目標状態の外にいったん動かす操作が必 要である。

3.2 閉ループ系の解析 制御則 (8)，（9)を式(4)に 代入すると

$$
\left\{\begin{array}{l}
\dot{X}_{1}=-k_{s} X_{1}-\sigma \frac{s}{\alpha v} X_{2} \\
\dot{X}_{2}=-k_{s} X_{2}+\sigma \frac{s}{\alpha v} X_{1}
\end{array}\right.
$$

となる。一方，式(11)，(12)より $s$ との解析解を得る.

$$
\left\{\begin{array}{l}
s(t)=s_{0} e^{-\sigma t}, \quad s_{0} \equiv s(0) \\
v(t)=v_{0} e^{-2 k_{s} t}, \quad v_{0} \equiv v(0)
\end{array}\right.
$$

$v$ の定義式(10)ょり， $X_{1}$ と $X_{2}$ の解の形を次式で表す.

$$
\left\{\begin{array}{l}
X_{1}(t)=\sqrt{v_{0}} \cos \nu(t) e^{-k s t} \\
X_{2}(t)=\sqrt{v_{0}} \sin \nu(t) e^{-k_{s} t}
\end{array}\right.
$$

式(14)，(15)を式(13)に代入して整理すると

$$
\begin{aligned}
& \dot{\nu}(t)=\nu_{1} e^{-\lambda t} \\
& \nu_{1} \equiv \frac{\sigma s_{0}}{\alpha v_{0}}, \quad \lambda \equiv \sigma-2 k_{s}
\end{aligned}
$$

を得る. 積分して

$$
\begin{aligned}
& \nu(t)=\nu_{0}+\frac{\nu_{1}}{\lambda}\left(1-e^{-\lambda t}\right) \\
& \sin \nu_{0} \equiv \frac{X_{2}(0)}{\sqrt{\nu_{0}}}, \quad \cos \nu_{0} \equiv \frac{X_{1}(0)}{\sqrt{v_{0}}}
\end{aligned}
$$

を得る。これを式(6)，(15) に代入して状態 $\left(x_{1}, x_{2}, \theta\right)$ の 解析解を得る。

$$
\begin{aligned}
x_{1}(t) & =x_{1 f}+\sqrt{v_{0}} \cos \nu(t) e^{-k_{s} t} \\
x_{2}(t)= & x_{2 f}+\sqrt{v_{0}} \sin \nu(t) e^{-k_{s} t} \\
\theta(t)= & \theta_{f}+s_{0} e^{-\sigma t} \\
& +\sqrt{v_{0}} \sqrt{x_{1 f}{ }^{2}+x_{2 f}{ }^{2}} \sin \left(\nu(t)-\nu_{f}\right) e^{-k s t} \\
\sin \nu_{f} & \equiv \frac{x_{2 f}}{\sqrt{x_{1 f}{ }^{2}+x_{2 f}{ }^{2}}, \quad \cos \nu_{f} \equiv \frac{x_{1 f}}{\sqrt{x_{1 f}{ }^{2}+x_{2 f}{ }^{2}}}}
\end{aligned}
$$

式(18)，(19)，(20)より以下のことがわかる.

（1）制御則 ( 8)，（9)のもとで状態 $\left(x_{1}, x_{2}, \theta\right)$ はいず れも速さ $k_{s}$ で目標状態 $\left(x_{1 f}, x_{2 f}, \theta_{f}\right)$ に収束する.

（2）状態 $\left(x_{1}, x_{2}, \theta\right)$ はいずれも振動成分を持つ。この 成分は， $\lambda>0$ のとき時間とともに周期が長くなり十分時 間が経過した後には振動しなくなる， $\lambda=0$ のとき周期が

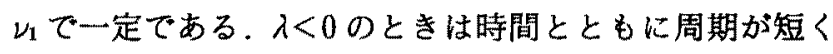
なる。

また，式(4)，(14），(15)より，制御入力は次式で表さ れる。

$$
\begin{aligned}
\boldsymbol{u}= & -k_{s} \sqrt{v_{0}} e^{-k_{s} t}\left[\begin{array}{l}
\cos \nu \\
\sin \nu
\end{array}\right] \\
& -\frac{\sigma s_{0}}{\alpha \sqrt{v_{0}}} e^{-\left(\sigma-k_{s}\right) t}\left[\begin{array}{c}
-\sin \nu \\
\cos \nu
\end{array}\right]
\end{aligned}
$$

よって制御入力が無限大にならないためには， $\sigma>k_{s} に と$

\begin{tabular}{ccc} 
第 1 表 & 状態変数の収束速度(滑り面を用いる制御) \\
\hline & 韭振動成分 & 振動成分 \\
\hline$x_{1}, x_{2}$ & - & $k_{s}$ \\
$\theta$ & $\sigma$ & $k_{s}$ \\
$s$ & $\sigma$ & - \\
$v$ & $2 k_{s}$ & - \\
\hline
\end{tabular}

れば十分である．さらに制御入力がチャタリングを生じな いためには，上の振動周期が発散しないことが必要てあ り, 式(16)より $\sigma \geq 2 k_{s}$ にとればよい.

状態変数の閉ループでの収束特性を第 1 表にまとめて示 す.

3.3 モテル化誤差の影響 滑り面を用いる制御では， $\alpha$ の推定值に含まれる誤差が滑り面の傾きに現れるが, 滑 り面に状態を引き寄せるとともに滑り面に浻って状態を原 点に移すように制御するため，モデル化誤差に対する感度 が低いと考えられる．以下では， $\alpha$ の推定値に誤差が含ま れる場合にも望ましい状態に指数的に収束可能なことを示 す.

$\alpha$ の推定值を $\widehat{\alpha}$ とる、 $\widehat{\alpha} に$ 誤差が含まれる場合には， 式(6)，(8)が次式のように書き変わる.

$$
\begin{aligned}
& \hat{s} \equiv X_{3}+\bar{\alpha}\left(x_{1} X_{2}-x_{2} X_{1}\right) \\
& \boldsymbol{u}_{s}=-\sigma \frac{\hat{s}}{\bar{\alpha} v}\left[\begin{array}{cc}
0 & 1 \\
-1 & 0
\end{array}\right]\left[\begin{array}{l}
X_{1} \\
X_{2}
\end{array}\right]
\end{aligned}
$$

式 (5)に制御則 (9)，(24)を代入して式(23)を用いて整理 すると次式を得る。

$$
\begin{aligned}
& \dot{s}=-\frac{\sigma \widehat{s}}{\widehat{\alpha}}\left\{\alpha-\tilde{\alpha}\left(x_{1, f} X_{2}-x_{2 f} X_{1}\right)\right\} \\
& \tilde{\alpha} \equiv \alpha-\widehat{\alpha}
\end{aligned}
$$

一方，式 (4)に制御則 (9)，(24)を代入すると

$$
\left\{\begin{array}{l}
\dot{X}_{1}=-k_{s} X_{1}-\sigma \frac{\hat{s}}{\hat{\alpha} v} X_{2} \\
\dot{X}_{2}=-k_{s} X_{2}+\sigma \frac{\hat{s}}{\hat{\alpha} v} X_{1}
\end{array}\right.
$$

を得る。ところで, 式(12)は $\widehat{\alpha} に$ 誤差が含まれる場合に も成り立つので，3.2節同様に $X_{1}$ と $X_{2}$ の解を式(15)の 形で表すことができる.よって，式(25)を以下のように書 き換える。

$$
\dot{s}+\frac{\alpha \sigma}{\widetilde{\alpha}} s=\frac{\sigma \alpha \tilde{\alpha}}{\widetilde{\alpha}} \sqrt{x_{1 f}{ }^{2}+x_{2 f}{ }^{2}} \sqrt{v} \sin \left(\nu-\nu_{f}\right)
$$

ここで, 右辺の $\sqrt{v}$ が速さ $k_{s} て ゙ 0 に$ 指数収束することか

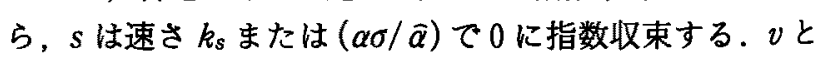

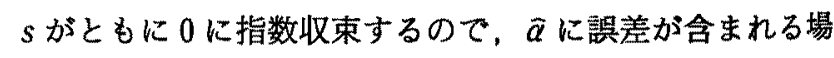
合にも望ましい状態に収束可能である。

\section{4. 時変項を用いる制御}

4.1 制御則の設計 非ホロノミックなシステムは, 自 律的な状態フィードバックによって平衡点を漸近安定化す ることはできないので，本節ては時間に陽に依存する項を 導入して平衡点を漸近安定化することを考光る。

次の形の制御則を用いる ${ }^{8)}$. 右辺第 1 項が $X_{1}, X_{2}$ につ 
いての比例制御である（ $k_{t}>0$ は制御ゲイン）．右辺第 2 項は，後述するように $X_{1} ， X_{2}$ を円周上に沿って動かすこ とて $s$ に生じる幾何学的位相を利用して $s$ を平衡点に近 づける制御である。

$$
\boldsymbol{u}=-k_{t}\left[\begin{array}{l}
X_{1} \\
X_{2}
\end{array}\right]+\left[\begin{array}{l}
f_{1}(s) \cos \omega t \\
f_{2}(s) \sin \omega t
\end{array}\right]
$$

$f_{1}(s)$ と $f_{2}(s)$ は $|s|$ に関する単調増加関数で次式を满たす ものとする。

$$
f_{1}(0)=0, \quad f_{2}(0)=0
$$

さて, $\boldsymbol{u}$ が第 2 項のみでかつ $f_{1}$ と $f_{2}$ が定数であるとす れば， $\omega$ の一周期における $s$ の変化分 $\Delta s$ は

$$
\Delta s=-2 \pi \alpha f_{1} f_{2}
$$

となる、よって， $f_{1}$ と $f_{2}$ の積が $s$ に比例するようにすれ ば，s の指数収束が期待できる。このことから $f_{1} と f_{2}$ を 式(31)のように定める.

$$
f_{1}=\varepsilon \operatorname{sign}(s) \sqrt{|s|}, \quad f_{2}=\varepsilon \sqrt{|s|}
$$

ここで $\varepsilon$ は制御パラメータである. $\operatorname{sign}(s)$ は, $s$ が負の ときにー1を、sが正の時に1を、sが 0 のときに0を出 力する符号関数である。

なお，本制御則は前述の制御則のような特異な点を持た

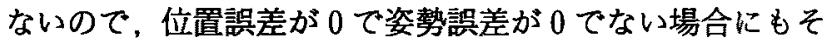
のまま適用できる。また，本制御則では，アームが閉曲線 を辿るときに生じる姿勢変動をその時点の状態変数から式 (30)で予測し，予測值に基づいて姿勢誤差をフィードバッ クしている， $n$ 自由度のアームについても同様に姿勢変動 を予測できると考えられるので6)，本制御則を $n$ 自由度の アームに抝張できる可能性がある。

4.2 閉ループ系の解析 制御則 (28) を構成するにあた $\eta$ ，右辺の $f_{1}$ と $f_{2}$ が $\omega$ の一周期で一定と見なすことがで きるという仮定をおいた（仮定 A)，本節では， $f_{1}$ と $f_{2}$ が 一定と見なして $X_{1}$ と $X_{2}$ の一般解を求め，その解を用い て $f_{1}$ と $f_{2}$ が時変であるとして状態変数の近似解析解を導 出する. 導出した近似解析解から仮定 A を満たすための 条件を明らかにする。

式(28)の $f_{1}$ と $f_{2}$ を一定と見なすと, 式(4)より $X_{1}$ と $X_{2}$ の一階の線形常微分方程式を得る。 その解の形は次式 のような斉次解と特解の線形和で与えられる。ここで, $C_{10}, C_{11}, C_{12}, C_{20}, C_{21}, C_{22}$ 蚁以下ように初期値とパ ラメー夕值で決まる定数である。

$$
\begin{aligned}
& X_{1}=C_{10} e^{-k_{t} t}+\left(C_{11} \cos \omega t+C_{12} \sin \omega t\right) f_{1} \\
& X_{2}=C_{20} e^{-k_{t} t}+\left(C_{21} \cos \omega t+C_{22} \sin \omega t\right) f_{2} \\
& C_{10}=X_{1}(0)-C_{11} f_{1}(0), \quad C_{11}=C_{22}=\frac{k_{t}}{k_{t}{ }^{2}+\omega^{2}} \\
& C_{20}=X_{2}(0)-C_{21} f_{2}(0), \quad C_{21}=-C_{12}=\frac{-\omega}{k_{t}{ }^{2}+\omega^{2}} \\
& \text { 上式を式(5)に代入して } \\
& \dot{s}= \alpha\left\{\left(C_{20} f_{1} \cos \omega t-C_{10} f_{2} \sin \omega t\right) e^{-k_{t} t}\right. \\
&\left.-\frac{\omega}{k_{t}{ }^{2}+\omega^{2}} f_{1} f_{2}\right\}
\end{aligned}
$$

第 2 表 状態変数の収束速度 (時変項を用いる制御)

\begin{tabular}{lcc}
\hline & 非振動成分 & 振動成分 \\
\hline$x_{1}, x_{2}$ & $k_{t}$ & $\beta$ \\
$\theta$ & $2 \beta$ & $\beta$ \\
$s$ & $2 \beta$ & $k_{t}$ \\
\hline
\end{tabular}

を得る.ここで新しい変数 $\chi(t)$ を導入する.

$$
x \equiv \sqrt{|s|}
$$

後述するようにsは 0 に指数収束するので次の近似が成 り立つ.

$$
\begin{aligned}
& s \simeq \chi^{2} \operatorname{sign}\left(s_{0}\right) \\
& f_{1} \simeq \varepsilon \operatorname{sign}\left(s_{0}\right) \chi, \quad f_{2}=\varepsilon \chi
\end{aligned}
$$

この近似を式(34)に代入し，両辺を $2 \operatorname{sign}\left(s_{0}\right) \chi て ゙$ 除して 整理すると次式を得る.

$$
\dot{\chi}=\frac{\alpha \varepsilon}{2}\left\{C_{20} \cos \omega t-\operatorname{sign}\left(s_{0}\right) C_{10} \sin \omega t\right) e^{-k_{t} t}-\beta \chi
$$

$$
\beta \equiv \frac{\alpha \omega \varepsilon^{2}}{2\left(k_{t}^{2}+\omega^{2}\right)}
$$

式(38)を積分して $\chi$ の近似解析解を得る.

$$
\begin{aligned}
& \chi=C_{30} e^{-\beta t}+\left(C_{31} \cos \omega t+C_{32} \sin \omega t\right) e^{-k_{t} t} \\
& C_{30}=\chi(0)-C_{31} \\
& C_{31}=\frac{\alpha \varepsilon}{2} \frac{\left(\beta-k_{t}\right) C_{20}+\omega \operatorname{sign}\left(s_{0}\right) C_{10}}{\left(\beta-k_{t}\right)^{2}+\omega^{2}} \\
& C_{32}=\frac{\alpha \varepsilon}{2} \frac{\omega C_{20}-\left(\beta-k_{t}\right) \operatorname{sign}\left(s_{0}\right) C_{10}}{\left(\beta-k_{t}\right)^{2}+\omega^{2}}
\end{aligned}
$$

要約すると, 閉ループ系での状態变数の近似解析解は次 の 5 ステップの手順で算出される.

$\mathrm{S} 1:$ 式(39)より $\chi$ を算出.

$\mathrm{S} 2: \chi$ を式(36)に代入して $s$ を算出.

$\mathrm{S} 3: \chi$ を式(37)に代入して $f_{1}, f_{2}$ を算出.

$\mathrm{S} 4: f_{1}, f_{2}$ を式(32)，(33)に代入して $X_{1}, X_{2}$ を算出. $\mathrm{S} 5:$ 式(6)より $X_{3}$ を算出.

$\chi$ の近似解析解(39)において，右辺第 1 項は $\beta$ の速さ で収束するが. 第 2 項は角周波数 $\omega$ で振動しその振幅は $k_{t}$ の速さで収束する. 式(37)より $f_{1}$ と $f_{2}$ は $\chi$ に比例す る。したがって，仮定 A を満たすためには，式(28)の右 辺第 1 項が $f_{1}$ と $f_{2}$ よりも十分に収束が早く， $f_{1}$ と $f_{2}$ の変 化が角周波数 $\omega$ と比べて十分に遅くなるように制御パラ メータを設定すればよい，すなわち，仮定 A を満足する ためには

$$
\beta \ll \min \left(k_{t}, \omega\right)
$$$$
\text { とすれば十分である。 }
$$

閉ループ系の状態変数の収束特性を第 2 表にまとめて示 す．収束の速さが異なる複数の項がある場合には，最も遅 い值を選んだ。

4.3 モデル化誤差の影響 $\alpha$ の推定值に誤差が含まれ る場合には付録に示すように振動成分が隇衰せずに残る。 そこで， $\alpha$ の推定則を併用する。

$$
\text { 式(2)上り姿勢角速度 } \dot{\theta} \text { の推定值 } \dot{\hat{\theta}} \text { は }
$$




$$
\dot{\hat{\theta}}=\widehat{\alpha}\left(-u_{2} x_{1}+u_{1} x_{2}\right)
$$

となる.よって推定則を次式のように構成する。ここで, $k_{\alpha}>0$ は推定ゲインである.

$$
\dot{\bar{\alpha}}=\frac{k_{a} \dot{\bar{\theta}}}{-u_{2} x_{1}+u_{1} x_{2}}, \quad \tilde{\theta} \equiv \theta-\hat{\theta}
$$

式 (2)，(41)，(42)より推定誤差 $\tilde{\alpha}$ のダイナミクスは

$$
\dot{\tilde{\alpha}}+k_{\alpha} \tilde{\alpha}=0
$$

となり, 速さ $k_{\alpha}$ で推定誤差が 0 に指数収束する.

\section{5. 数値シミュレーション例}

5.1 シミュレーション条件 本章では， $3 ， 4$ 章で検 討した制御則および推定則の有効性を数值シミュレーショ ンで確認する、まず，パラメータ推定䛊差がない場合につ いてシミュレーションを行い, 状態が目標值に取束するこ とおよび $3.2,4.2$ 節で導出した近似解析解がシミュレー ション值とよく一致することを示す. 次に，パラメータ推 定誤差がある場合についてシミュレーションを行い，推定 誤差がある場合にも状態が目標值に収束することを示す.

制御目標の数值例として,アームを $x$ 方向にー-1.0 $[\mathrm{m}], y$ 方向に $1.0[\mathrm{~m}]$ 移動させてその間に姿勢を 90 [deg]反時計回りに変化させることを考える.シミュレー ションで用いるロボットの質量特性, 初期条件と終端条 件，ならびに制御パラメータをそれぞれ第 3 表，第 4 表お よび第 5 表に示す.なお，パラメータ推定誤差がある場合 として，本体の慣性モーメント $i_{s}$ の真值が推定值の初期 值よりも $50 \%$ 大きい場合について数值シミュレーション を行う。このとき， $\alpha$ の值は 0.67 になる（ $\alpha$ の推定值の 初期值 $\widehat{\alpha}_{0}$ は 1.0).

5.2 滑り面を用いる制御 $\alpha$ の推定誤差がない場合お

\begin{tabular}{|c|c|c|c|}
\hline 項 目 & 記号 & 数値 & 単位 \\
\hline 本体質量 & $m_{s}$ & 50 & $\mathrm{~kg}$ \\
\hline 本体の慣性モーメント & $i_{s}$ & 12 & $\mathrm{kgm}^{2}$ \\
\hline ハンドの䁈量 & $m_{h}$ & 10 & $\mathrm{~kg}$ \\
\hline 質量パラメータ & $\alpha$ & 1.0 & $1 / \mathrm{m}^{2}$ \\
\hline
\end{tabular}
よびある場合について，滑り面を用いる制御を運動方程式 （1）。（2）に適用して数值積分した結果を第 3 図および第

第 4 表 初期条件と終端条件

\begin{tabular}{lccl}
\hline \multicolumn{1}{c}{ 項 目 } & 記号 & 数値 & 単位 \\
\hline ハンドの初期位置 & $\left(x_{1 s}, x_{2 s}\right)$ & $(1.0,0.0)$ & $\mathrm{m}$ \\
本体の初期姿勢 & $\theta_{s}$ & 0 & $\mathrm{rad}$ \\
ハンドの目標位置 & $\left(x_{1 s}, x_{2 s}\right)$ & $(0.0,1.0)$ & $\mathrm{m}$ \\
本体の目標姿勢 & $\theta_{s}$ & $\pi / 2$ & $\mathrm{rad}$ \\
\hline
\end{tabular}

第 5 表 制御パラメータ

\begin{tabular}{lcc}
\hline 項 目 & 記号 & 数值 \\
\hline 滑り面を用いる制御 & $k_{s}, \sigma$ & $0.1,0.2$ \\
時変項を用いる制御 & $k_{t}, \omega, \varepsilon$ & $0.1,1.0,0.246$ \\
$\alpha$ の推定則 & $k_{a}$ & 0.3 \\
\hline 単位はすへて $[1 / \mathrm{s}]$. & &
\end{tabular}

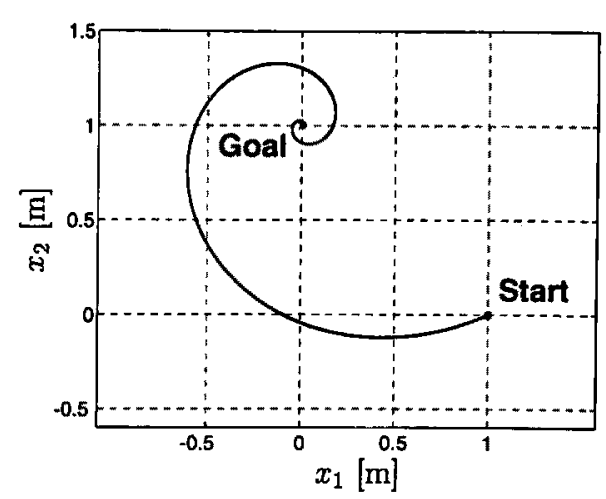

(a) アームの轨道

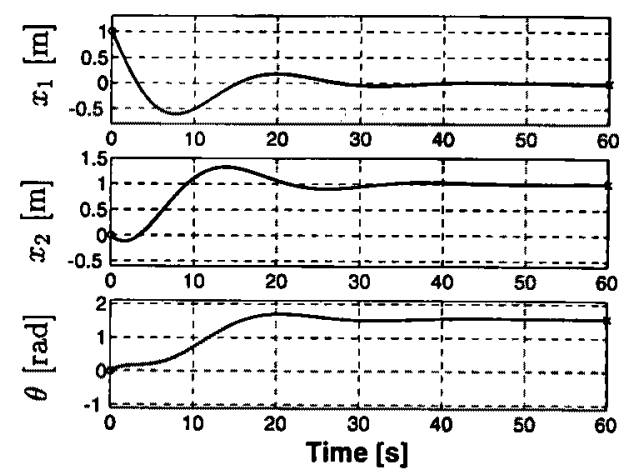

(b) 状態変数の時间履歷

(実線: シミュレーション, 破線: 解析解 (18),(19),(20))
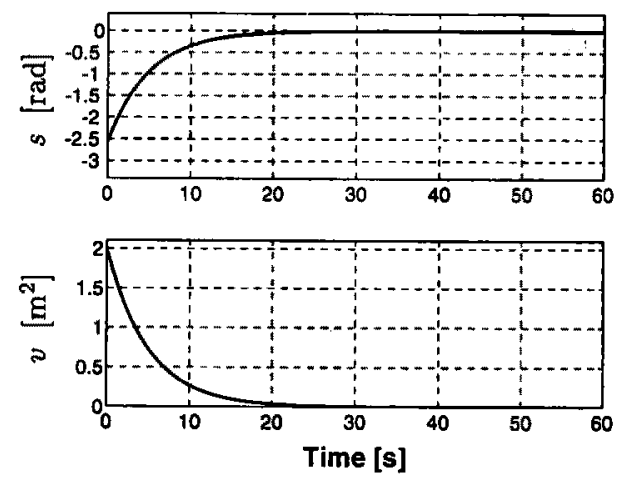

(c) $s, v$ の時间履歷

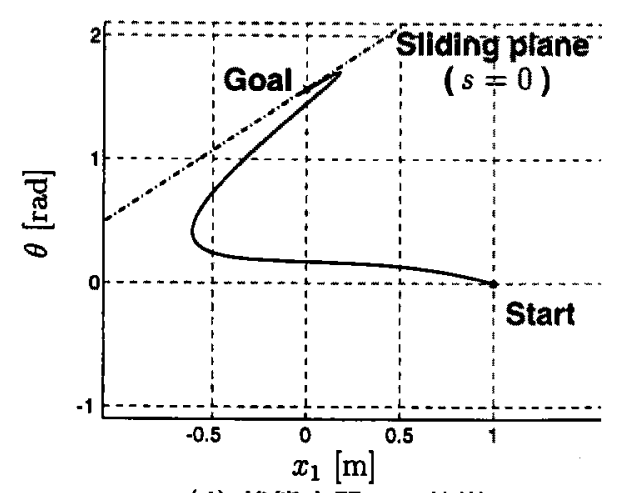

(d) 状热空間での轨道 ( $-x_{2}$ 軸方向から見た堨合 $)$

第 3 図 数值シミュレーション結果 滑り面を用いる制御（推定誤差なし） 
4 図に示す。数值積分のステップ幅は 0.1 [s] とし，積分 には 4 次の Runge-Kutta-Gill 法を用いる.

第3 図において，まず,グラフ(a)はアームの䩔道 $\left(x_{1}\right.$, $\left.x_{2}\right)$ を $x_{l} y_{t}$ 座標平面に示したものである.グラフ $(\mathrm{b})$ は, 上から順にアームの位置の $x_{1}$ 成分 $x_{1}$ と $y_{1}$ 成分 $x_{2}$ 拉よび 本体の姿勢 $\theta$ の時間履歴をプロットしたもので, 数值シ ミュレーション結果を実線で，また解析解を破線で示す. グラフ (a)，（b）ともに，初期状態に記号○を，目標状態 に記号×を付す．グラフ(c)には，状態と滑り面との距離 $s$ とアームの位置誤差 $v$ の時間履歴を示す.グラフ $(\mathrm{d})$ に は， $-x_{2}$ 軸加ら眺めたときの状態空間における状態 $\left(x_{1}\right.$, $\left.x_{2}, \theta\right)$ の軌道捛よび滑り面 $(s=0)$ を示す. 滑り面はこの とき直線として見えるので，一点鎖線でプロットする，

第 4 図のグラフの定義は第 3 図と同様であるが、グラフ (b)には推定誤差がある場合のシミュレーション結果（実 線）の他に，推定誤差がない場合のシミュレーション結果 （破線）を比較のため示す.

なお，本体の慣性モーメント $i_{s}$ の真値が推定值の初期 值よりも50\%小さい場合についても数值シミュレーショ ンを行い，滑らかに目標状態に収束していることを確認し ている.

第 3 図より以下のことがわかる.

（1）(a)より，目標地点を取り囲むように近づいて目 標値に収束している。（d)より, 制御開始後しばらくは滑 り面に向かって状態が移動し，その後で滑り面に沿うよう にして目標値に収束している.

（2）（b)より，解析解(18)，(19)，(20)はシミュレー ション結果と重なって区別が付かず，よく一致している.

(3) (c)において, $s, v$ の収束の時定数は 5 秒程度と 読みとれる。この例では式(11)，(12)に示される $s ， v$ の 収束の速さ $\sigma, 2 k_{s}$ がともに $0.2[/ \mathrm{s}]$ (時定数に換算する と $5[\mathrm{~s}])$ であることに対応する.

第 4 図より以下のことがわかる.

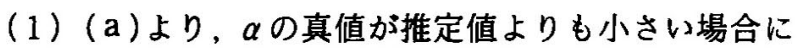
は目標点の周囲を回る回数を增やすことで大きな姿勢変動 を作り出している，(d)より，滑り面 $(s=0) に$ 近づくよ うに状態が振動しながら目標值に収束している.

（2）（c）において，s は推定誤差のために単調減少で はなくなりまた収束の速さも遅くなっている，vは，3.3 節で述べたよう，推定誤差がある場合にも同じ速さ $2 k_{s}$ で収束する。

5.3 時㚆項を用いる制御 $\alpha$ の推定誤差がない場合お よびある場合について，時変項を用いる制御を運動方程式 （1），（2）に適用して数値積分した結果を第 5 図および第 6 図に示す。数值積分のステップ幅は 0.1 [s] とし，積分 には 4 次の Runge-Kutta-Gill 法を用いる. 4.3 節で述べ たように, 時変項を用いる制御ではバラメータ推定則を併 用する。

各図において，グラフ(a ), (b)の定義は前節と同様で

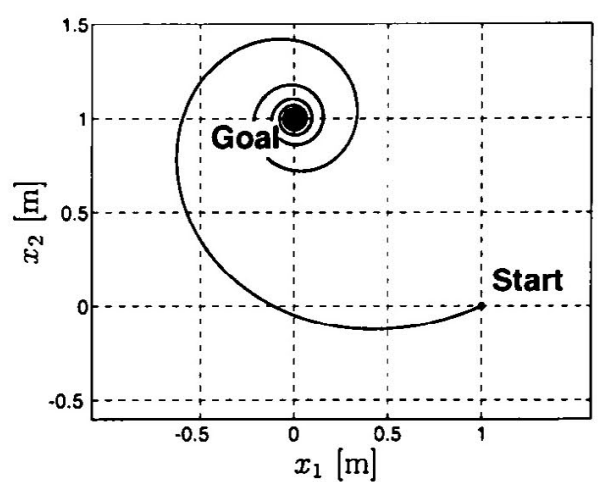

(a) アームの轨道

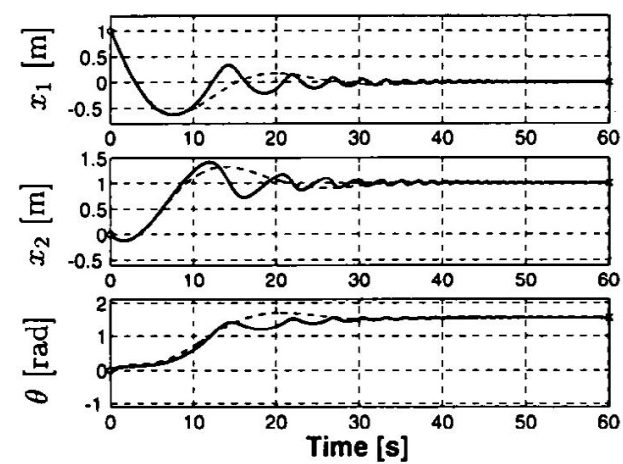

(b) 状態変数の時間履歴

(実線: 推定諤差あり，破線: 推定證差なし)
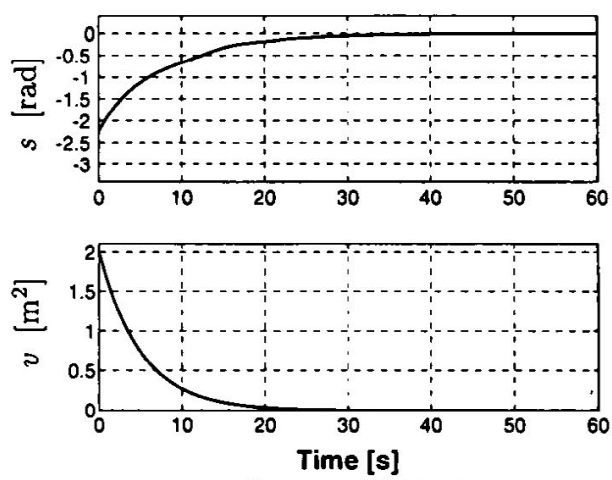

(c) $s, v$ の時間履歴

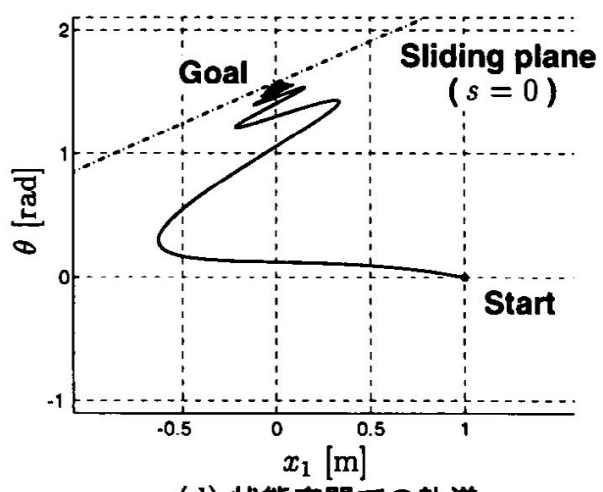

(d) 状慜空間での浡道 ( $-x_{2}$ 粙方向から見た場合)

第 4 図 数値シミュレーション結果 滑り面を用いる制御（ $\left.\alpha=0.67 \hat{\alpha}_{0}\right)$ 


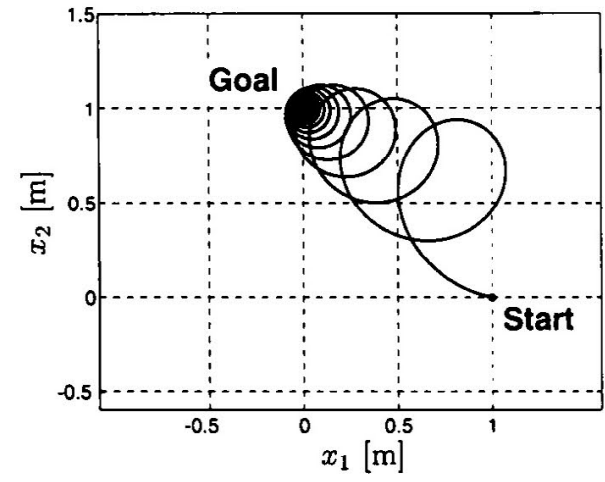

(a) アームの轨道

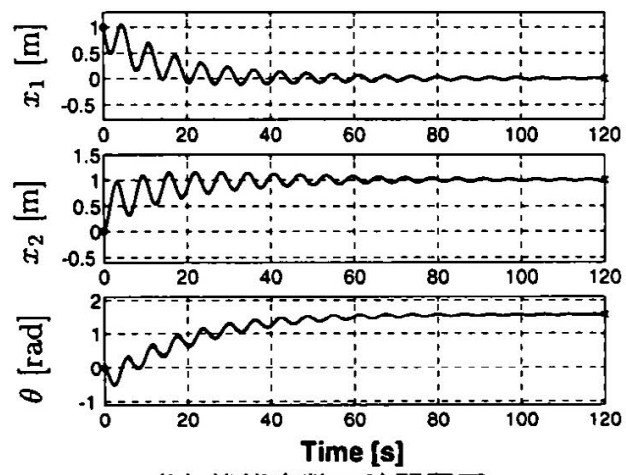

(b) 状態変数の时間履歴

(実線: シミュレーション, 破線: 解析解 (39))
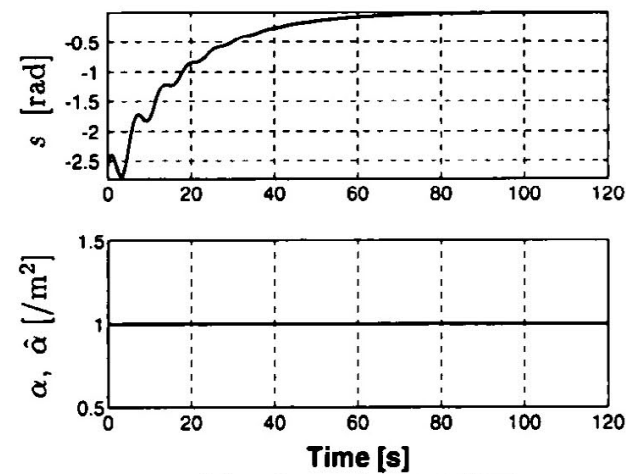

(c) $s$ およびôa の時間属歴

(実線: 推定值, 一点鎖楾: 真値)

第 5 図 数值シミュレーション結果

時㚆項を用いる制御（推定誤差なし）

ある.グラフ $(\mathrm{c}) に は$, 変数 $s$ と推定值 $\hat{\alpha}$ の時間履歴を 示す。なお，本体の慣性モーメント $i_{s}$ の真值が推定値の 初期值よりも50\%小さい場合についても数值シミュレー ションを行い，滑らかに目標状態に収束していることを確 認している.

第 5 図より以下のことがわかる.

（1）(a)より，アームの小刻みな回転を繰り返しなが らその回転半径を少しずつ小さくして目標状態に収束して いる.

(2) (b)より, 解析解 (39) はシミュレーション結果と 重なって区別が付かず，よく一致している。

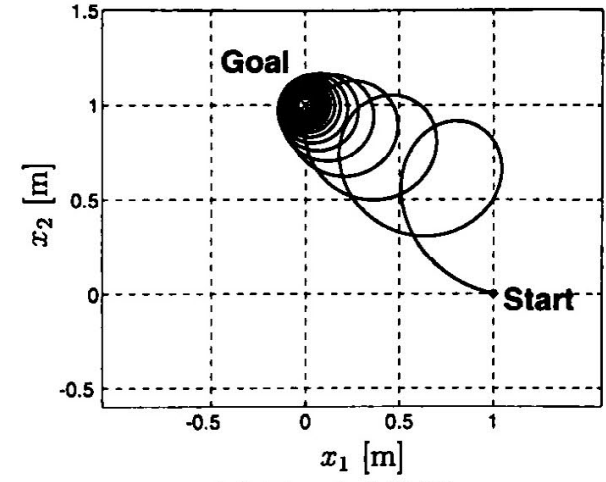

(a) アームの轨道

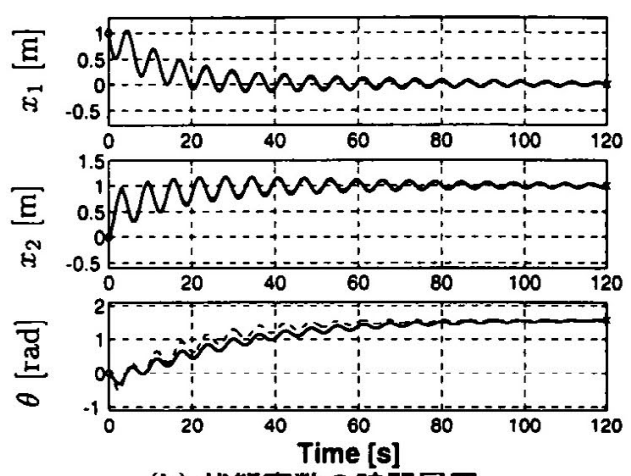

(b) 状愿变数の時间履歴 (実線: 推定誤差あり，破線: 推定铞差なし)
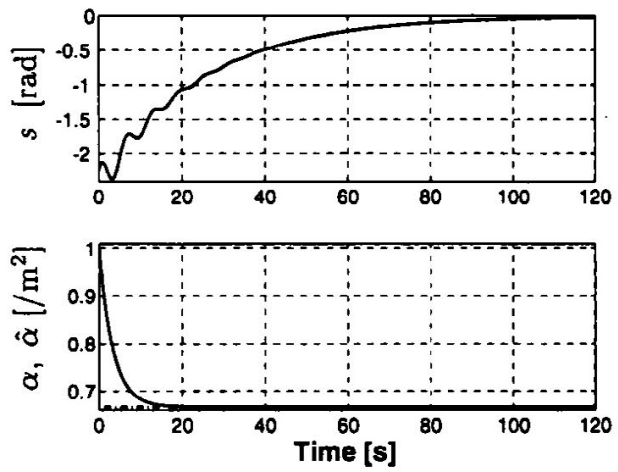

(c) $s$ および $\hat{\alpha}$ の時间履歴

(実線: 推定値, 一点鎖線: 真値)

第6図数值シミュレーション結果 時変項を用いる制御 $\left(\alpha=0.67 \widehat{\alpha}_{0}\right)$

（3）（c）において，sは単調減少てはないがその符号 は一定（この例では負）に保たれており，4.2節で解析解 を導出する際に用いた近似「 $s$ の符号は一定」は妥当であ る.

第6図より以下のことがわかる。

（1）（a）上り， $\alpha$ の真值が推定値よりも小さい場合に は回転半径を大きくすることで必要な姿勢変動を作り出し ている.

（2）（c）において，sは単調減少ではないがその符号 は一定（この例ては負）に保たれており，4.2節で解析解 を導出する際に用いた近似「 $s$ の符号は一定」は $\alpha$ に推定 
誤差がある場合にも妥当である.

\section{6. 結 論}

本稿ては,アームの運動によって宇宙ロボットの本体の 姿勢が変動することに着目し，アームの運動による姿勢制 御について考察した。

2 自由度のアームを 1 本持つ宇宙ロボットの平面運動に ついて，(1)滑り面を用いる制御：ある滑り面を定義し て，その面に近づくような制御とその面に沿って目標点に 移動するような制御の組み合わせ，（2）時変項を用いる制 御：時間に陽に依存する項を導入し，アームを小刻みに回 転させることで姿勢誤差を連続的にフィードバック，の 2 つの制御則を検討した。

各制御則について，閉ループ系の状態変数の解析解を導 出し，いずれの制御則においても状態を望ましい状態に指 数収束させることができることを示した。また，収束の速 さと制御ゲインの関係を明らかにした。モデル化誤差とし て，質量パラメータの推定誤差の影響について考察した。 時変項を用いる制御では推定誤差に対する感度が高いの で，質量パラメータの推定則を導入した，滑り面を用いる 制御では，推定誤差がある場合でも状態を望ましい状態に 収束させることができることを示した．数值シミュレーシ ヨンにより制御則および推定則の有効性を確認した。

今後は， $n$ 自由度アームへの抎張を検討する予定であ る.

\section{参 考 女 献}

1）山田克彦, 吉河章二：可動部を有する人工衛星の適応的な姿勢制 御, 計測自動制御学会論文集, 31 (1995)，pp. 1678-1685.

2）小田光茂：ETS-VIによる宇宙ロボットの軌道上実験一衛星搭載 ロボットアームと衛星姿勢の協調制御一，日本機械学会口ボティ クス・メカトロニクス講演会講演論文集, 1994, pp. 937-940.

3) Vafa, Z. and Dubowsky, S.: On the Dynamics of Space Manipulators Using the Virtual Manipulator, with Applications to Path Planning, J. Astronaut. Sci., 38 (1990), pp. 441472.

4) Longman, R. W.: The Kinetics and Workspace of a SatelliteMounted Robot, J. Astronaut. Sci., 38 (1990), pp. 423-440.

5）中村仁彦：非ホロノミック系制御研究の展望，計測と制御， 36 (1997), pp. 384-389.

6）山田克彦：宇宙ロボットのアーム運動による本体姿勢のフィー ドパック制御，システム制御情報学会論文誌，9 (1996)，pp. 296304.

7) Khennouf, $\mathrm{H}$. and de Wit, C.: On the Construction of Stabiliz ing Discontinuous Controllers for Nonholonomic Systems, Proc. IFAC Nonlinear Control Systems Design, 1995, pp. 667672
8) M'Closkey, R. and Murray, R. : Nonholonomic Systems and Exponential Convergences: Some Analysis Tools, Proc IEEE Conference on Decision and Control, 1993, pp. 943-948.

\section{付録：時变項を用いる制御の定常特性 (众に誤差がある場合)}

$\alpha$ の推定値に誤差がある場合には，式(31)が次のように 書き変わる。

$$
\bar{f}_{1}=\varepsilon \operatorname{sign}(\hat{s}) \sqrt{|\hat{s}|}, \quad \bar{f}_{2}=\varepsilon \sqrt{|\hat{s}|}
$$

仮定 Aのもとで $X_{1}, X_{2}$ の解の形が式(32)，(33)で与え られる ( $f_{1}, f_{2}$ は $\hat{f}_{1}, \hat{f}_{2}$ に置き換わる).

推定值 $\bar{s}$ と真值 $s$ の間に次の関係が成り立つことに注 意すると

$$
\bar{s}=s-\tilde{\alpha}\left(x_{1 f} X_{2}-x_{2 f} X_{1}\right)
$$

式(34)が次のように書き変わる。

$$
\begin{aligned}
\dot{\vec{s}}= & \alpha\left(\left(C_{20} \hat{f}_{1} c_{\omega}-C_{10} \hat{f}_{2} s_{\omega}\right) e^{-k_{t} t}-\frac{\omega}{k_{t}^{2}+\omega^{2}} \hat{f}_{1} \hat{f}_{2}\right\} \\
& -\tilde{\alpha}\left\{\left(-x_{1 f} C_{20}+x_{2 f} C_{10}\right) k_{t} e^{-k_{t} t}\right. \\
& -k_{t} x_{1 f}\left(C_{11} c_{\omega}+C_{12} s_{\omega}\right) \hat{f}_{1} \\
& \left.+k_{t} x_{2 f}\left(C_{21} c_{\omega}+C_{22} s_{\omega}\right) \hat{f}_{2}+x_{1 f} \hat{f}_{2} s_{\omega}-x_{2 f} \hat{f}_{1} c_{\omega}\right\}
\end{aligned}
$$

$c_{\omega} \equiv \cos \omega t, \quad s_{\omega} \equiv \sin \omega t$

新しい変数 $\chi$ を導入する。

$$
\chi^{2} \equiv|\hat{s}|
$$

このとき式(A.3)は

$$
\begin{aligned}
2 \chi \dot{\chi} \operatorname{sign}\left(\hat{s}_{0}\right)= & \alpha\left\{\left(C_{20} \operatorname{sign}\left(\hat{s}_{0}\right) c_{\omega}-C_{10} s_{\omega}\right) e^{-k_{t} t}\right. \\
& \left.-\frac{\omega}{k_{t}^{2}+\omega^{2}} \varepsilon \operatorname{sign}\left(\hat{s}_{0}\right) \chi\right\} \varepsilon \chi \\
& -\tilde{\alpha}\left(-x_{1 f} C_{20}+x_{2 f} C_{10}\right) k_{t} e^{-k_{t} t} \\
& -\bar{\alpha}\left\{-k_{t} x_{1 f}\left(C_{11} c_{\omega}+C_{12} s_{\omega}\right) \operatorname{sign}\left(\hat{s}_{0}\right)\right. \\
& +k_{t} x_{2 f}\left(C_{21} c_{\omega}+C_{22} s_{\omega}\right) \\
& \left.+x_{1 f} s_{\omega}-x_{2 f} \operatorname{sign}\left(\hat{s}_{0}\right) c_{\omega}\right\} \varepsilon \chi \quad \text { (A.5) }
\end{aligned}
$$

となる。

4.2 節と同様に式(A.5)の両辺を $\chi \operatorname{sign}\left(\widehat{s}_{0}\right)$ で除すこと を考える。このとき，右辺第 3 項より減衰のない正弦波成 分が牫る。な枋，右辺第 2 項については， $\tilde{\alpha}=0$ のをに $\chi$ の収束の速さが $\beta$ であったことおよび $k_{t} \gg \beta$ が成り立 つことから， $\chi \operatorname{sign}\left(\hat{s}_{0}\right)$ で除して得られる成分も収束して 発散することはない。このように，時変項を用いる制御で は， $\bar{\alpha}$ に誤差が含まれる場合に振動成分が残る。 